\title{
Analisis Penerapan Model Pembelajaran Mean Ends Analysis pada Peningkatan Hasil Belajar Siswa
}

\author{
Mince Limu ${ }^{1}$, Yohanis Umbu Kaleka ${ }^{2}$, Melkianus Suluh ${ }^{3}$ \\ ${ }^{1-3}$ Program Studi Pendidikan Fisika, STKIP Weetebula
}

\author{
*Mince Limu: \\ Program Studi Pendidikan Fisika; \\ STKIP Weetebula, Sumba Barat Daya; \\ Email: mincelimu94@gmail.com
}

\begin{abstract}
Abstrak: Tujuan penelitian ini adalah untuk menganalisis model pembelajaran Mean Ends Analysis dalam peningkatan hasil belajar siswa. Teknik pengumpulan data berasal dari sumber resmi sekunder berupa artikel jurnal dan skripsi. Metode penelitian yang digunakan adalah penelitian deskriptif. Yang berarti mengambarkan masalah yang harus dirumuskan sehingga memudahkan peneliti untuk menganalisis data hasil pengamatan atau rata-rata serta presentasenya. Berdasarkan hasil kajian dari jurnal dan skripsi yang relevan bahwa kemampuan siswa dalam proses belajar menciptakan pembelajara yang aktif dan menyenangkan. Sesuai indikator keberhasilan bahwa pemahaman siswa dalam pembelajaran dengan menggunakan model pembelajaran Mean Ends Analysis dapat disimpulkan bahwa dapat meningkatkan hasil belajar siswa.
\end{abstract}

Kata Kunci: Hasil Belajar, model pembelajaran Mean Ends Analysis

Abstract: The purpose of this study was to analysis learning model in improving student lerning outcomes. Data collection techniques came from secondary official sources in the form of jornal and theses artcles. The research method used is descriptive research which mean describing the problem that it makes it easier for researcher to analyze the observed data or the average and the percentage. Based on the result of the study of the relevant journals and theses, the ability of students in the learning proces creates active and enjoyable learning. According to the success indicators that students' understanding in learning using the Mean Ends Analysis learning model can be concluded that it can improve student learning outcomes.

Key word: Learning outcomes, Mean Ends Analysis learning model

\section{PENDAHULUAN}

Pendidikan adalah usaha yang diwujudkan dalam proses pemnbelajaran secara aktif dalam mengembangkan potensi dirinya atau rangkaian peristiwa yang kompleks, dan juga sebagai rangkaian kegiatan yang komunikasinya dengan manusia.Sehingga manusia juga memiliki pribadi yang utuh atau memiliki usaha melalui belajar, oleh karena itu pengajar tidak dapat melepaskan diri dari mengajar. Pendidikan merupakan suatu proses yang melalui pembentukan dan pengembangan kepribadian, intelektual, dan emosional secara seimbang. Sebagaimana tercantum UUD sistem pendidikan nasional no 20 Tahun 2003 bahwa" pendidikan adalah usaha sadar dan perencana untuk mewujudkan suasana belajar dan proses pembelajaran agar siswa secara aktif mengembangkan potensi dirinya unutk memiliki kekuatan spiritual, keagamaan, pengendalian diri, kepribadian, kecerdasan, ahlak mulia serta ketrampilan yang diperlukan diri masyarakat, bangsa dan Negara" dari definisi diatas dapat dikatan bahwa melalui pendidikan seseorang harus mampu mengembangkan potensi dirinya.

Pembelajaran merupakan suatu system yang terdiri dari berbagai komponen yang saling berhubungan satu dengan yang lain. Komponen tersebut meliputi: tujuan, materi, metode, dan evaluasi, keempat komponen pembelajaran tersebut harus diperhatikan oleh guru dalam memilih dan menentukan pendekatan, dan modelmodel pembelajaran yang akandigunakan dalam kegiatan pembelajaran.

Model pembelajaran Mean Ends Analysis dikembangkan pertama kali oleh Newel dan 
Simon pada Tahun 1972 (Huda, 2014:294) yang menyatakan bahwa Mean Ends Analysis merupakan salah satu teknik yang digunakan dalam Artificial intelligence untuk mengontrol upaya pencarian dalam program computer pemecahan masalah. MEA juga dikatakan sebagai salah satu cara untuk mengklarifikasi gagasan seseorang ketika melakukan pembuktian. Model pembelajaran Mean Ends Analysis itu ada karena salah satu model pembelajaran yang mengoptimalkan kegiatan pemecahan masalah berupa rangkaian pertanyaan dengan memberikan petunjuk untuk membantu siswa dalam penyelesaian masalah yang dihadapi.

Tujuan model Mean Ends Analysis (MEA) merupakan metode pemikiran yang dalam penerapannya dijadikan dalam beberapa tujuan yang pada akhirnya menjadi beberapa langkah atau tindakan berdasarkan konsep yang berlaku langkah itu sendiri untuk mencapai tujuan yang lebih umum dan rinci, Model pembelajaran Mean Ends Analysis juga mengembangkan berfikir refleksi, kritis, logis, sistematis, dan kreatif. Shoimin 2014.

Menurut muklason (2019) guru lebih dominan menerapkan model pembelajaran konvensional menyebabkan ketuntasan secara klasikal sehingga materi fisika siswa belum tercapai. Masalah tersebut perlu adanya perbaikan pembelajaran melalui penyelidikan masala, cara yang digunakan, dan tujuan pembelajaran, maka digunakan model pembelajaran Mean Ends Analysis untuk meningkatkan hasil belajar fisika peserta didik.

Langkah-langkah model pembelajaran Means-Ends-Analysis. Adapun langkah-langkah pembelajran Means Ends Analisis suatu model pembelajran yang mengoptimalkan kegiatan pemecahan masalah melalui pendekatan hauristik yaitu berupa rangkaian pertanyaan yang merupakan petunjuk untuk membantu siswa dalam memecahkan masalah yang di hadapinya.

Model pembelajaran tersebut tidak dapat mengatasi semua aspek permasalahan pembelajaran tersebut. Suatu model pemebelajara pasti memiliki kelebihan dan kekurangan .begitu juga dengan model pembelajaran Mean Ands Analisis.Kelebihan dan kekurangan model pemebelajaran tersebut muncul pada model itu sendiri.

Menurut Shoimin. (2014:103) 1. Tujuan pembelajaran dijelaskan kepada siswa 2. Memotivasi siswa terlibat dalam aktivitas pemecahan masalah yang dipilih 3 . Siswa dibantu mendefinisikan dan menggorganisasikan tugas belajar yang berhubungan dengan masalah tersebut (menerapkan topik, tugas, dan lain-lain) 4. Siswa dikelompokan menjadi 5 atau 6 kelompok (kelompok yang dibentuk harus heterogen). Masing-masing kelompok diberi tugas /soal pemecahan masalah. 5 . Siswa dibimbing untuk mengidentifikasi masalah, menyederhanakan masalah, hipotesis, mengumpulkan data, membuktikan hipotesis, dan menarik kesimpulan.6. Siswa dibantu untuk melakukan refleksi atau evaluasi terhdap penyelidikan mereka dan proses-proses yang mereka gunakan.7. Siswa dibimbing untuk menyimpulkan materi yang telah dipelajari. Kelebihan model pembelajaran MEA.

Kelebihandan kekurangan model pembelajaran Mean Ends Analysis (MEA) Menurut Shoimin. (2014:104-105) 1. siswa terbiasa memecahkan masalah/ menyelesaikan soal-soal pemecahan masalah. 2. siswa berpartisivasi lebih aktif dalam pembelajaran dan sering mengekpresikan idenya. 3. siswa memiliki kesempatan lebih banyak dalam memanfaatkan pengetahuan dan ketrampilan. 4. siswa dengan kemampuan rendah dapat merespon permasalahan dengan cara mereka sendiri. 5. siswa memiliki pengalaman banyak untuk menentukan sesuatu dalam menjawab pertanyaan melalui diskusi kelompok MEA memudahkan peserta didik memecahkan masalah.

Kekurangan model pembelajaran Mean Ends Analysis(MEA). Membuat soal pemecahan masalah yang bermakna bagi siswa bukan merupakan hal yang muda. 1. Mengemukan masalah yang berlangsung dapat dipahami siswa sangat sulit sehingga banyak peserta didik yang mengalami kesulitan bagaimana merespon masalah yang diberikan. 2. Lebih dominan soal pemecahan masalah terutama soal yang terlalu sulit untuk dikerjakan, terkadang membuat perta didik jenuh. 3. Sebagian siswa bisa merasa bahwa kegiatan belajar tidak menyenangkan karena kesulitan yang mereka hadapi.

Jadi berdasarkan teori diatas dapat disimpulkan bahwa model pembelajaran MeanEndsAnalysis (MEA) merupakan model pembelajaran yang membagi peserta didik dalam kelompok untuk menyelesaikan masalah dalam proses pembelajaran.

\section{Metode Penelitian}

Penelitian ini bertujuan untuk mengidentifikasi model pembelajaran Mean Ends Analysis pada peningkatan hasil belajar siswa. Sumber yang digunakan dalam 
penelitian ini adalah sumber yang berkaitan dengan model pembelajaran Mean Ends Analysis Sumber tersebut berupa jurnal dan skripsi yang relevan dengan permasalahan yang diteliti sebanyak 5 jurnal artikel dan 1skripsi. Jurnal dan skripsi yang diambil dimulai dengan tahun terbaru.

Keberhasilan siswa dalam pemebelajaran dengan menggunakan model pembelajaran yang sesuai dengan keadaan siswa dan keterlibatan siswa cukup aktif dalam pembelajaran.Menurut (muklason, 2019) menyatakan bahwa pembelajaran menggunakan model pembelajaran Mean Ends Analysis dapat meningkatkan hasil belajar. Model pembelajaran Mean Ends Analysis juga telah berhasil membuat seluruh siswa tertarik saat belajar dan menyenangkan sehingga berdampak singnifikan terhadap hasil belajar.

Berdasarkan hasil penelitian yang ditemukan pada artikel jurnal bahwa hasil belajar siswa dipengaruhi model pembelajaran yang digunakan. Dimana siswa menggunakan model pembelajaran Mean Ends Analysis (MEA) memperoleh hasil yang memuaskan atau lebih tinggi dari pada siswa yang menggunakan model pembelajaran konvensional. untuk mengetahui apakah hasil belajar siswa terjadi peningkatan atau memenuhi KKM, maka peneliti menggunakan penelitian tindakan kelas (PTK) Dan penelitian ekperimen memberikan tes berupa soal. Pada penelitian tidakan kelas diberikan tes hasil belajar pada pembelajaran menggunakan model pembelajaran Mean Ends Analysis (MAE). Dilihat dari nilai KKM apakan sudah tercapai atau belum. Jika belum maka perlu memberikan pembelajaran lagi dengan menggunakan model pembelajaran Mean Ends Analysisdengan cara memberikan tes hasil belajar berupa soal sehingga bisa mencapai KKM.

\section{HASIL DAN PEMBAHASAN}

Berdasarkan hasil penelitian yang diperoleh pada artikel jurnal dan skripsi yang dilakukan oleh Peneliti (muklason, 2019) dikelas $X$ KA 1 SMK Negeri 1 mojonyar dengan subjek berjumlah 34 orang siswa hasil belajar siswa diukur vengan menggunakan lembar penilaian atau instrument tes hasil belajar. Dengan demikian hasil tes diperoleh hasil bahwa dengan menggunakan model pembelajaran Mean Ends Analysis (MEA). Dengan hasil belajar menunjukan peningkatan dari $67,65 \%$ pada $\mathrm{pra}$ siklus menjadi $79,41 \%$ pada siklus pertama. dan pada siklus kedua mencapai $91,18 \%$ maka ketuntasan hasil belajar siswa secara klasikal meningkat pada siklus kedua.

Penelitian yang dilakukan oleh (Ashari, 2017 )dikelas VIII SMP 14 Banjarmasih dengan subjek berjumlah 32 orang siswa. Hasil belajar siswa diukur melalui tes berupa soal evaluasi, sehingga dari hasil tes tersebut dipeoleh bahwa dengan menggunakan model pembelajaran Mean Ends Analysis (MEA) terjadi peningkatan hasil belajar pada siklus 1 diperoleh $65,63 \%$ dan ketuntasan klasikal mencapai 96,88\% pada siklus ke 2 .

Penelitian yang dilakukan oleh (jusmawati, 2018) kelas X SMA Negeri 9 makassardengan subjek penelitian 35 orang siswa hasil belajar siswa diukur dengan menggunakan pretest sebelum menggunakan model pembelajaran Mean Ends Analysis sebagai tes awal untuk mengetahui kemampuan siswa. Kemudian setelah beberapa kali pertemuan siswa kembali diberikan posttest sebagai tes akhir untuk mengetahui kemampuan siswa setelah digunakan model pembelajaran Mean Ends Analysis (MEA) maka diketahui bahwa model pembelajaran Mean Ends Analysisdapat meningkatkan hasil belajar.

Penelitian yang dilakukan oleh (Isnainiyah dkk 2019) dengan subjek penelitian adalah siswa kelas VIII-A SMP Muhammadiyah 10 surabaya. hasil belajar diukur dengan hasil tes dan observasi banyaknya siswa yang tuntas pada siklus I sebesar 69,23\% meningkat menjadi $88,46 \%$ pada siklus II. Proses pembelajaran pada siklus I dan siklus II mengalami peningkatan yang terlihat pada kategori bertanya pada guru, berdiskusi antara teman atau guru, menyampaikan pendapat, dan mengerjakan LKS.

Penelitian yang dilakukan oleh (Susanti dkk 2019) dengan sampel penelitian menggunakan teknik purposive sampling, sampel penelitian ini adalah siswa kelas VII 8 sebagai kelas ekperimen dengan menerapkan model pembelajaran Mean Ends Analysis (MEA) Dan kelas VII 9 Sebagai kelas kontrol dengan menerapkan pembelajaran ekspositori. Nilai ratarata eksperimen adalah 55,19 dan nilai rata-rata kelas kontrol adalah 42,79.Nilai rata-rata kelas eksperimen lebih tinggi dari nilai rata-rata kelas kontrol.Maka hasil belajar siswa yang menggunakan model pembelajaran Mean Ends Analysis (MEA) lebih baik dari pada hasil belajar siswa yang menggunakan pembelajaran ekspositori.

Dari hasil penelitian para peneliti terdahulu di atas siswa dituntut lebih aktif dalam proses pembelajaran dimana siswa harus menyelesaikan masalah dalam proses 
pembelajaran yang berlangsung dan menggali pendapatnya masing-masingdan memberikan kesempatan kepada siswa untuk merumuskan jawaban, kemudian siswa menjawab pertanyaan.

Berdasarkan kegiatan pembelajaran dari para peneliti terdahulu di atas, dapat dipahami bahwa pada pembelajaran dengan menggunakan model Mean Ends Analysis hasil belajar siswa lebih baik dibandingkan dengan model pembelajaran konvensional.

\section{PEMBAHASAN}

Model Pembelajaran Mean ends Analysis itu ada karena salah satu model pembelajaran yang mengoptimalkan kegiatan pemecahan masalah berupa rangkaian perranyaan dengan memberukan petunjuk untuk membantu siswa dalam penyelesaian masalah yang duhadapi dan mampu berfikir kreatif dan cermat sehingga memperoleh. Pengalaman belajar yang lebih bermakna dalam pembelajaran sehingga dapat meningkatkan hasil belajar.

Tahapan model pembelaharan Mean Ends Analysis pada peningkatan hasil belajar siawa. Pembelajaran akan lebih bermakna jika siswa diberi kesempatan untuk Tahu dan terlibat aktif dalam menemukan masalah dari fakta-fakta yang dilihat dari lingkungan maupun di dalam kelas dengan bimbingan guru untuk menggekspresikan idenya dalam pendidikan saat ini.

\section{KESIMPULAN DAN SARAN \\ Kesimpulan}

Sesuai hasil yang dilakukan oleh peneliti terdahulu dengan mengumpulkan data, menganalisis data, melalui artikel jurnal, dan skripsi, untuk memperoleh informasi dan menganalisis data serta membuat kesimpulan. Melalui proses pembelajaran yang menggunakan model pembelajaran Mean Ends Analysis. Maka hasil kajian dari 5 jurnal dan 1 skripsi dapat disimpulkan. bahwa model pembelajaran Mean Ends Anaysis dapat meningkatkan hasil belajar siswa.

Saran

Berdasarkan kesimpulan di atas, Adapun saran yang dapat disampaikan dalam penelitian ini adalah sebagai berikut:

Berdasarkan hasil penelitian terdahulu yang telah dikaji di atas, maka peneliti menyarankan agar dalam kegiatan pembelajaran diharapkan guru bisa memilih model yang tepat dan sesuai dengan materi pembelajaran untuk memperkuat konsep-konsep atau masalah yang telah ditemukan tentang model pembelajaran Mean Ends Analysis agar proses pembelajaran berjalan dengan efektif dan efisien sehingga penelitian ini dapat dijadikan bahan referensi bagi generasi selanjutnya.

\section{Daftar Pustaka}

Huda, Muftahul. 2016. Model-Model Pengajaran dan Pembelajaran. Yogyakarta. Pustaka Pelajar.

Isnainiyah, A, M. dkk. 2019. Penerapan pendekatan heuristik dengan model pembelajaran Mean Ends Analysis (MEA) untuk meningkatkan hasil belajar siswa. Jurnal seminal nasional pendidikan matematika. 2019.

Jusmawati, Sri. 2018. Pengaruh metode pembelajaran mean ends analysis (MEA) terhadap hasil belajar fisika peserta didik SMA Negeri 9 Makassar. Skripsi universitas muhammadiyah makassar fakultas keguruan dan ilmu pendidikan. 2018.

Muklason, Akhmad. 2019. Penerapan model mean ends analysis (MEA) untuk meningkatkan hasil belajar siswa materi fluida. Jurnal inovasi pendidikan fisika dan integrasinya.2 (2). 2019. 